\title{
Quality Determination of Red Radish by Nondestructive Root Color Measurement
}

\author{
Monika Schreiner, Angelika Krumbein, Ilona Schonhof, and Stefanie Widell \\ Institute of Vegetable and Ornamental Crops Großbeeren/Erfurte.V., Department of Quality, Großbeeren, \\ Germany \\ Susanne Huyskens-Keil \\ Humboldt-University Berlin, Institute for Horticultural Sciences, Section Quality Dynamics / Postharvest \\ Physiology, Berlin, Germany
}

\begin{abstract}
AdDitional IndeX words. glucosinolates, pectic substances, monosaccharides, colorimeter, postharvest, Raphanus sativus
Abstract. A new approach for nondestructive quality assessment based on color measurement was developed for red radishes (Raphanus sativus L.). Postharvest changes in hue angle corresponded with changes in soluble and insoluble pectic substances linked to textural characteristics in 'Nevadar' radishes. Changes in glucosinolates were related to changes in chroma and were associated with radish flavor. However, monosaccharides were not related to root color during the 4 days of postharvest period. Nevertheless, the data suggest that root color may be used as a rapid, inexpensive and reliable indicator of quality during the postharvest distribution of radish.
\end{abstract}

Great attention is being given to vegetable quality in terms of flavor, nutritional and health benefits, and shelf life due to surplus production, strong local and international competition, and rising consumer awareness regarding diet-health connections (Lennernäs et al., 1997). Therefore, quality control is increasingly important, and more attention has been focused on nondestructive methods for rapid, easy, and reliable assessment of external and internal product quality, especially following harvest (De Bardemaeker, 1993).

Identifying correlations between characteristic external and internal product attributes, e.g., between color and carbohydrates, will be necessary for nondestructive estimates of product quality. Correlations already have been established for melons and apples where product quality is regularly determined by nondestructive methods in commercial sectors (Kawano et al., 1993; Winter et al., 1992).

In the present study, untopped bright red radish (Raphanus sativus L.) roots, preferred by German consumers (Schreiner et al., 1999), were used to test a nondestructive method for quality determination. The goal was to relate root color measured by a colorimeter to the contents of glucosinolates, monosaccharides, and pectic substances that influence flavor and texture desired components for a high radish quality. Widell et al. (1998) reported that 1) glucosinolates provide the flavor and pungent, intensive, and burning aftertaste attributes, and 2) glucose and fructose influence the sweet taste attribute. The crispy mouth feel impression is reported to be predominantly determined by the ratio of pectic fractions (Huyskens-Keil et al., 1998).

Purchasing decisions at product delivery are often based on absolute values of quality compounds. Quality assurance measures during storage, handling, and display can also be influenced by the initial, absolute value, as for example, a lower initial quality may indicate faster deterioration, and thus shorter shelf life in the distribution system. However, the content of quality determining compounds, e.g., color of many vegetables and fruit, changes during development and is known to be influenced by the various

Received for publication 30 Apr. 2002. Accepted for publication 2 Jan. 2003. This research was supported by the German research association. We also gratefully acknowledge the critical and helpful review and fruitful comments of Adel A. Kader, and we thank Leopold M.M. Tijskens for the critical comments on statistical concerns. pre- and postharvest factors such as cultivation period, developmental stage, and postharvest conditions (Kader, 2002; Kays, 1991; Kays, 1999; Schreiner et al., 2000; Shewfelt and Prussia, 1993). In red radishes, variations in hue angle and chroma were affected by the developmental stage, preharvest temperature, and irradiation (Schreiner and Huyskens-Keil, unpublished data). According to Beverly et al. (1993), plants integrate their individual environmental conditions into physiological responses leading to varying contents of chemical quality compounds during plant development from germination to senescence. Therefore, the main issue in evaluating postharvest quality should be the assessment of the rate of changes in quality. Hence, the success of quality assurance systems has to be measured in relative changes and not in absolute values. In the present investigation, harvest values of red radish root color (hue angle and chroma) were compared with values obtained several times after harvest. Postharvest changes in quality characteristics were then calculated as the difference between after-harvest and initial values. Therefore, responses are expressed in terms of relative change $(\Delta)$ in the following sections. Gnanasekharan et al. (1992) and Giovanelli and Lavelli (2002) used the same approach in comparing color values taken at harvest and during postharvest handling and processing of green vegetables and tomatoes. This approach will be useful for a more comprehensive assessment of postharvest treatments on the physiological dynamics of quality, and thus, will allow the evaluation of different quality assurance systems. On the other hand, for purchasing decisions and selective quality control the use of absolute quality values will meet customer requirements.

The objective of the present investigation was to examine the extent of associations between radish root color and compositional changes, i.e., using root color as indicator of monosaccarides, pectic substances and glucosinolates. Root color may then be used in rapid, easy, and reliable assays to estimate quality control.

\section{Materials and Methods}

Plant material and postharvest treatments. Untopped 'Nevadar' radish was selected for study based on its high preference in consumer acceptance tests in Germany (Schreiner et al., 1999). 'Nevadar' forms a bright red, round root consisting predominantly of thickened hypocotyl tissue. 
For this study, we chosed to explore relationships in radishes grown in different seasons and harvested at different physiological stages in order to collect data of a spectrum of pre- and postharvest factors (e.g., cultivation period, developmental stage, and postharvest conditions) affecting quality. The current experimental design was a randomized block design with three replications. The block consisted of one plot per replicate. Each plot was $2 \times$ $4 \mathrm{~m}$ with 2,600 plants. Radishes were harvested only from the inner 10 rows of the plot in May and June 1997 and in July 1998 at the experimental station of Humboldt University in Berlin. Fertilization, irrigation, and plant protection corresponded to the guidelines of the integrated cultivation for radishes (Winkhoff, 1992). Root physiological stage at harvest was defined according to the $\mathrm{BBCH}$ codes (Biologische Bundesanstalt für Land- und Forstwirtschaft, Bundessortenamt, Chemical industry) of Bleiholder et al. (1997). The first number (1 to 9) of the digit code describes the principal growth stage, and the second number $(0$ to 90) characterizes the secondary growth stage (expressed as a percentage of final expected root diameter). For example, a $\mathrm{BBCH}$ code of ' 43 ' indicates the growth stage (4) "development of harvestable vegetative plant parts" with $30 \%$ (3) of the expected root diameter.

The radishes were harvested according to German quality standards (Bickelmann, 1996) and selected for uniformity in root diameter $(\mathrm{BBCH} 43=24 \pm 1 \mathrm{~mm}$, equal to $30 \%$ root diameter; $\mathrm{BBCH} 45=26 \pm 1 \mathrm{~mm}$, equal to $50 \%$ root diameter; $\mathrm{BBCH} 47$ $=28 \pm 1 \mathrm{~mm}$, equal to $70 \%$ root diameter; $\mathrm{BBCH} 49=30 \pm 1$ $\mathrm{mm}$, equal to $90 \%$ root diameter), root shape (round, not oval), and visual appearance (freedom of defects and disorders). The studies were carried out with radishes of the BBCH stages 43 , 45, 47, and 49.

After harvest, radishes were placed in open trays $(1.00 \times 0.50$ $\mathrm{m})$ and held in environmental chambers $\left(5 \mathrm{~m}^{3}\right.$ air volume; Linde, Hamburg) for up to $4 \mathrm{~d}$ under different postharvest conditions simulating distribution and marketing. These conditions included the following.

1) An air temperature of $18{ }^{\circ} \mathrm{C}$ combined with $>95 \%$ relative humidity characterizing the conditions within commercial packages. Radish roots at BBCH stages from 43 to 49 were used for this experiment, which was replicated four times.

2) An air temperature of 5 to $8^{\circ} \mathrm{C}$ combined with $>95 \%$ relative humidity represented marketing in cooled, mist-equipped display cases and short-term storage in cold rooms. Radishes were held in chambers without light since light level is negligible in storage rooms and in supermarket outlet cases. Radish roots at $\mathrm{BBCH}$ stages of 43 and 45 were stored for this experiment, which was repeated two times.

Temperature sum was used as a measure of the cumulative effects of temperature on physiological processes and chemical composition. In the present study, a temperature sum was calculated as the sum of the mean temperature for each hour of the postharvest period.

Additionally, the increase in vegetative biomass of radish plants per day was calculated for determining the growth rate which influence physiological processes. The growth rate per day was computed by determining the fresh matter at harvest in relation to days of cultivation.

Determination OF QUALITY CHARACTERISTICS. For the determination of chemical quality compounds, mixed samples of 30 roots were prepared before, during, and after storage. Color and chlorophyll fluorescence were measured on 40 roots before, during, and after storage. Root material for pectin analyses was diced and $10 \mathrm{~g}$ of each sample was frozen in liquid nitrogen and kept at $-28^{\circ} \mathrm{C}$ until analysis. For the determination of glucosinolates and monosaccharides, radish roots were frozen $\left(-28^{\circ} \mathrm{C}\right)$, freeze dried, and ground to a fine powder.

Harvest values of all investigated characteristics (color, chlorophyll fluorescence, chemical compounds) were compared with values obtained at several times during postharvest storage. Relative values $(\Delta)$ were then calculated as the difference between after-harvest values and initial values.

ROOT COLOR. Root color was measured with a colorimeter (LR 321; Minolta Camera Co., Osaka, Japan) using a standardized light type D65. Calibration was conducted using a white standard tile. Color measurements were expressed in the L*a*b* scale, where $\mathrm{L}^{*}$ indicates the luminescence, $\mathrm{a}^{*}$ represents the green-red color axis, and $b^{*}$ the blue-yellow axis. Color was recorded on each of 40 roots at harvest, and during and after storage for each experiment. Ten color measurements were made equatorially on each root and four derived functions were computed from the recorded $\mathrm{L}^{*}, \mathrm{a}^{*}$, and $\mathrm{b}^{*}$ values as follows:

Chroma $\quad C=\left[\left(a^{*}\right)^{2}+\left(b^{*}\right)^{2}\right]^{1 / 2}$

Hue angle $\quad H=\tan ^{-1}\left(b^{*} / a^{*}\right)$

Chroma difference $\quad \Delta C=\left[\left(a^{*}\right)^{2}+\left(b^{*}\right)^{2}\right]^{1 / 2}-\left[\left(a^{*}{ }_{0}\right)^{2}+\left(b^{*}{ }_{0}\right)^{2}\right]^{1 / 2}$

Hue angle difference $\Delta H=\left[\tan ^{-1}\left(b^{*} / a^{*}\right)\right]-\left[\tan ^{-1}\left(b^{*}{ }_{0} / a^{*}{ }_{0}\right)\right]$ where $a^{*}{ }_{0}$ and $b^{*}{ }_{0}$ represent the respective values at harvest.

Chlorophyll Fluorescence Measurement. Chlorophyll fluorescence values explain changes in quality attributes (chroma, glucosinolates) based on physiological processes, and thus, alterations in physiological age were monitored using chlorophyll fluorescence during storage at 5 to $8^{\circ} \mathrm{C}$ and $18^{\circ} \mathrm{C}$. Chlorophyll fluorescence was measured on the first pair of leaves after a 20 min adaptation to darkness and to room temperature $\left(20^{\circ} \mathrm{C} \pm 1\right.$ ${ }^{\circ} \mathrm{C}$ ) with a Mini-Pam (Walz, Effeltrich). A pulse-modulated light source was used. The intensity of the measuring actinic light was $<0.02 \mu \mathrm{mol} \cdot \mathrm{m}^{-2} \cdot \mathrm{s}^{-1}$. This allowed an accurate assessment of the minimal fluorescence $\left(\mathrm{F}_{0}\right)$ (van Kooten and Snel, 1990). A saturating light pulse of $3000 \mu \mathrm{mol} \cdot \mathrm{m}^{-2} \cdot \mathrm{s}^{-1}$ was applied to determine the maximal fluorescence $\left(\mathrm{F}_{\mathrm{m}}\right)$. During the experiment, chlorophyll fluorescence was recorded in the middle of each leaf of 40 radishes at harvest, and during and after storage of $4 \mathrm{~d}$. Four chlorophyll fluorescence measurements (two measurements on each leaf of the first leaf pair) were taken for each of the 40 radishes.

Glucosinolates. A modified HPLC method of Lange et al. (1991) was used for glucosinolate determination. Freeze dried root tissue $(0.5 \mathrm{~g})$ was extracted in $10 \mathrm{~mL}$ of a 7 methanol : 3 water mixture (by volume, $\mathrm{T}=70^{\circ} \mathrm{C}$ ), which was immersed for 1 min in a $75^{\circ} \mathrm{C}$ water bath. The extract was then centrifuged with the addition of $2 \mathrm{~mL} 0.4 \mathrm{~m}$ barium acetate (Merck, Darmstadt). The supernatant was removed and the residue was extracted two additional times as described above. The supernatants were combined and brought up to a volume of $25 \mathrm{~mL}$ with the methanol/water mixture. Five grams DEAE-Sephadex A-25 (Sigma Chemie, Deisenhofen) was mixed with $200 \mathrm{~mL}$ deionized water and then activated with $5 \mathrm{~mL}$ $1 \mathrm{~N} \mathrm{CH}_{3} \mathrm{COOH}$. The supernatant was decanted and the Sephadex was neutralized with deionized water. An empty $1 \mathrm{~mL}$ Bakerbond spe polypropylene column (Mallinckrodt Baker, Gross-Gerau) was packed with $200 \mu \mathrm{L}$ activated Sephadex between two $20 \mu \mathrm{m}$ polyethylene frits. A sample of the extract $(5 \mathrm{~mL})$ was applied to a DEAE-Sephadex A-25 anion exchange column and washed with $10 \mathrm{~mL}$ deionized water. After the application of $250 \mu \mathrm{L}$ purified arylsulphatase solution (Boehringer Mannheim, Mannheim) and a $12 \mathrm{~h}$ incubation, desulfonated glucosinolates were eluted with 3 mLdeionized water. Analysis of desulfoglucosinolates was carried 
out with a HPLC (Bischoff, Leonberg) with UV-VIS-detector and a Spherisorb ODS2-column $(5 \mu \mathrm{m}, 250 \times 4 \mathrm{~mm})$ (Bischoff, Leonberg). Samples were analyzed using a gradient of $0 \%$ to $20 \%$ acetonitrile in water (2 to $34 \mathrm{~min}$ ), followed by $20 \%$ acetonitrile in water $(6 \mathrm{~min})$, then $100 \%$ acetonitrile $(10 \mathrm{~min})$. The analysis was carried out with a flow of $1.3 \mathrm{~mL} \cdot \mathrm{min}^{-1}$ and detection at $229 \mathrm{~nm}$. An aliquot of $10 \mu \mathrm{L}$ was used for analysis after passing through a $0.45-\mathrm{mm}$ filter (hydrophilic, Satorius, Minisart NML). Glucosinolate content was calculated using sinigrin as an external standard and the response factor of each compound relative to sinigrin. From each sample (three samples, 10 roots per sample), chemical assays were performed in duplicate.

Monosaccharides. Glucose and fructose were analyzed enzymatically using freeze-dried root tissue. Freeze-dried root tissue $(0.1 \mathrm{~g})$ was extracted in $30 \mathrm{~mL}$ hot deionized water. The solution was purified with $1 \mathrm{~mL}$ potassium hexacyanoferrate and $1 \mathrm{~mL}$ zinc acetate, then diluted to $50 \mathrm{~mL}$ with deionized water and filtered with a hard folded filter (Schleicher \& Schuell, Dassel). A $100 \mu \mathrm{L}$ sample was assayed with an enzymatic test kit (Boehringer Mannheim, 1986), where reduced nicotinamide adenine dinucleotide phosphate (NADPH) was formed during the reaction of the reducing sugars with hexokinase, adenosine 5 -triphosphate, nicotinamide adenine dinucleotide phosphate (NADP), glucose 6-phosphate dehydrogenase, and phosphoglucose isomerase. The absorbance of NADPH was measured spectrophotometrically at $340 \mathrm{~nm}$ (Spekol 221, Carl Zeiss, Jena). From each of three samples, which each consisted of 10 roots, chemical assays were performed in duplicate.

Pectic substances. The extraction of cell walls from radish roots was completed as described by McComb and McCready (1952), Blumenkrantz and Asboe-Hansen (1973) and modified by Huyskens (1991). Frozen tissue was blended in an Ultra-Turrax T25 (IKA, Staufen) with $99.9 \%$ (v/v) acetone/water, boiled for $20 \mathrm{~min}$, and the suspension was vacuum filtered. The residue on the filter paper (Schleicher and Schüll No 589/3, Dassel) was resuspended in $99.9 \%(\mathrm{v} / \mathrm{v})$ acetone/water, $70 \%(\mathrm{v} / \mathrm{v})$ ethanol/water and again in $99.9 \%(\mathrm{v} / \mathrm{v})$ acetone/water. The final white residue on the filter paper (Miracloth 475855, Calbiochem, Bad Soden) was dried overnight at $70^{\circ} \mathrm{C}$. This fraction, the alcohol insoluble solids (AIS), was weighed and stored in a vacuum desiccator over silica gel until further analysis.

The isolated AIS was fractionated into a water-soluble pectin fraction (WSP), an EDTA-soluble pectin fraction (EDTA-SP), and an insoluble pectin fraction (ISP) according to the method described by Blumenkrantz and Asboe-Hansen (1973). Pectin fractions were measured using the method described by $\mathrm{McComb}$ and McCready (1952). The amount of galacturonic acid in each fraction was measured as absorbance with a spectrophotometer (UV/VIS-8730, Philips, Cambridge) at $520 \mathrm{~nm}$. The measurement was carried out with five replications from each sample.

STATISTICAL ANALYSES. The results were analyzed by analysis of variance and calculation of regression $(P \leq 0.05)$ with STATISTICA (StatSoft Inc., 2001) and TableCurve (AISN Software Inc., 1997), respectively.Leastsignificant differences were calculated using Tukey's HSD test $(P \leq 0.05)$. Principal component analysis was conducted using the factor analysis procedure of STATISTICA (StatSoft Inc., 2001). The number of samples necessary for the color measurement ensuring a $P$ level of 0.05 was determined with CADEMO (Rasch et al., 1992). The presented data points are the means of six replications for glucosinolates and monosaccharides, means of five replications for pectic substances, and means of 40 replications for both color and chlorophyll fluorescence being measured on the same roots.

\section{Results and Discussion}

CORRELATION BETWEen RoOT COLOR AND PECTIC SUBSTANCES. According to Hardin (1990), human perception of hue angle differences of 2.5 units is possible. A difference of 1 to 2 units in $L^{*}$, $\mathrm{a}^{*}$, or $\mathrm{b}^{*}$ is noticeable to most observers (Berger-Schunn, 1994). This effect was also observed in 'Nevadar' radishes (Schonhof and Schreiner, unpublished data) and in strawberries (Holcroft and Kader, 1999). Moreover, color differences $<1$ to 2 units are also important for quality control as they may relate to preharvest stress (Tollner et al., 1993). Postharvest color changes of radish roots, described by $\Delta$ hue angle, correlated with the accumulation and loss of soluble and insoluble pectin, respectively (Fig. 1). An accumulation of insoluble pectin corresponded with a shift in hue angle toward decreased redness (orange-red), while loss of insoluble pectin correlated with increased redness (purplishred). Color descriptions are according to Voss (1992). Previous consumer acceptance tests found that purplish-red radishes and loss in crispness due to degradation of insoluble pectin corresponded with rejections for purchase and consumption (Schreiner et al., 1999)

The postharvest correlations of $\Delta$ insoluble pectic substances and $\Delta$ soluble pectic substances with $\Delta$ hue angle were attributed to postharvest temperature. Hue angle shifted to an increased redness to purplish red with increasing temperature and prolonged storage (Fig. 2). This might indicate that anthocyanins had degraded to aglycons (Forkmann, 1994). The red color of radish root periderm is due to the anthocyanin pelargonidin 3-sophoroside-5-glucoside (Herrmann, 1997; Mazza and Miniati, 1993). In several other crops anthocyanins are reported to be temperature sensitive (Böhm et al., 1998; Gennaro et al., 2002; Herrmann, 1991; Marais et al., 2001; Romero and Bakker, 2000; Wang and Stretch, 2001). Data collected here may be additional evidence that high temperatures impact color changes via the degradation of anthocyanins. The tendency for decreased redness to reddish-orange of the radish roots might be due to higher concentrations of pelargonidin 3sophoroside-5-glucoside in comparison to purplish-red roots, indicating no or less anthocyanin decomposition. Reddish-orange colored strawberries also had higher anthocyanin contents than scarlet colored fruit (Holcroft and Kader, 1999).

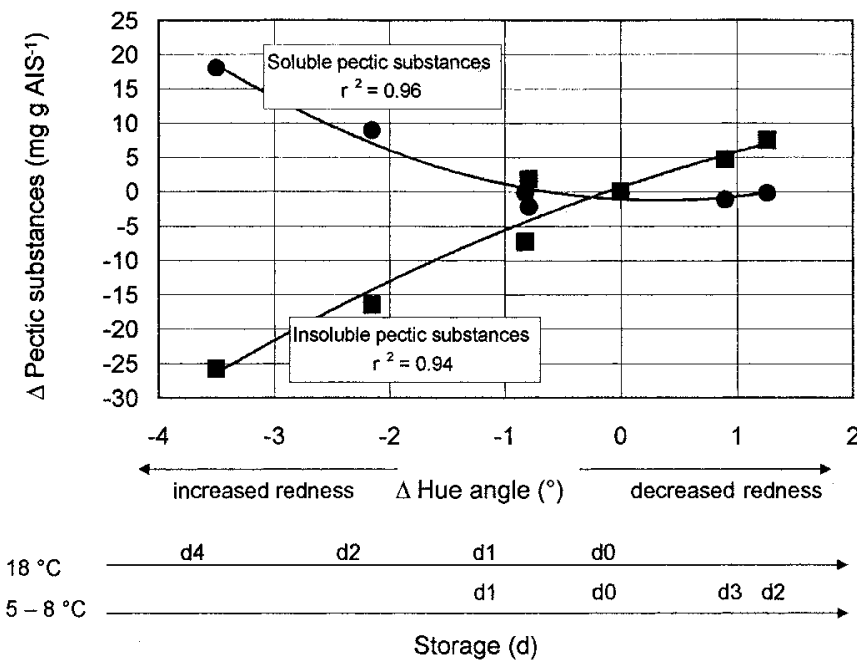

Fig. 1. Correlation between $\Delta$ pectic substances ( soluble pectic substances, insoluble pectic substances) and $\Delta$ hue angle of 'Nevadar' radish during postharvest handling hold at 5 to $8{ }^{\circ} \mathrm{C}$ and $18{ }^{\circ} \mathrm{C}$ up to $4 \mathrm{~d}$ of storage (BBCH 45 to $47 ; \mathrm{n}=320$ ). 

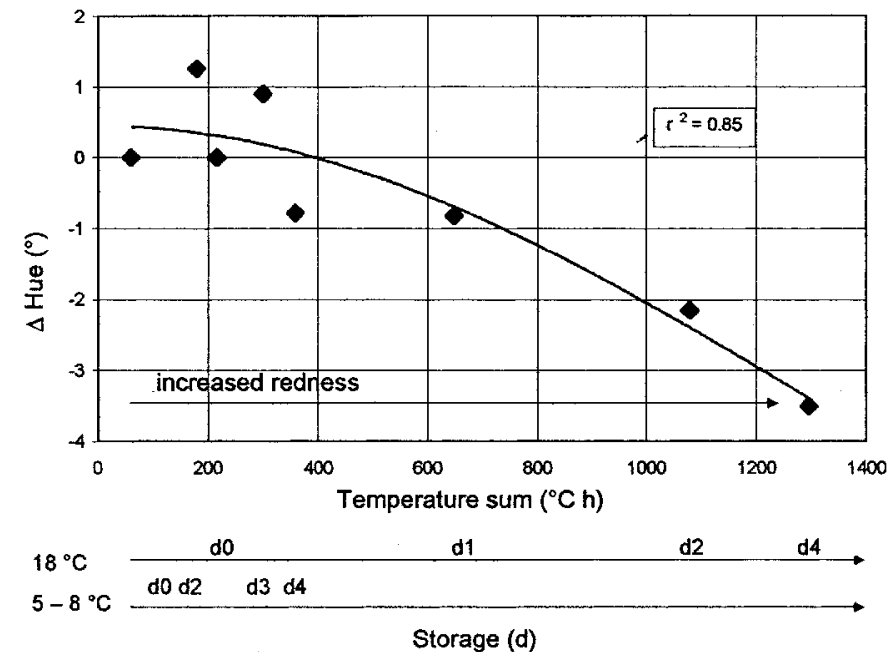

Fig. 2. Effect of temperature sum on $\Delta$ hue angle of 'Nevadar' radish during postharvest handling hold at 5 to $8{ }^{\circ} \mathrm{C}$ and $18{ }^{\circ} \mathrm{C}$ up to $4 \mathrm{~d}$ of storage $(\mathrm{BBCH}$ 45 to $47 ; \mathrm{n}=320$ ).

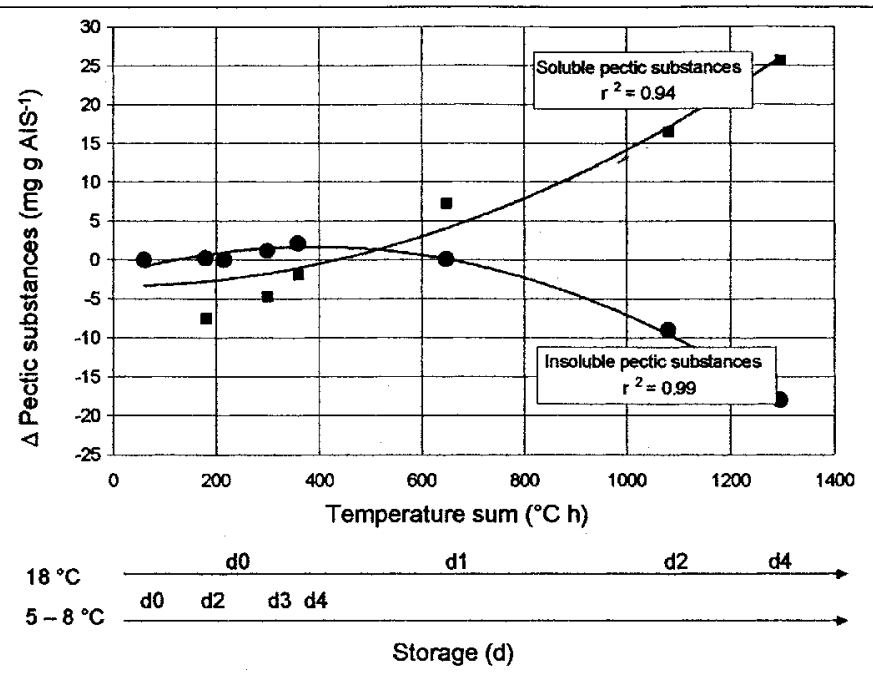

Fig. 3. Effect of temperature sum on $\Delta$ soluble pectic substances ( $\square)$ and $\Delta$ insoluble pectic substances $(\mathbf{)})$ of 'Nevadar' radish during postharvest handling hold at 5 to $8{ }^{\circ} \mathrm{C}$ and $18{ }^{\circ} \mathrm{C}$ up to $4 \mathrm{~d}$ of storage (BBCH 43 to $49 ; \mathrm{n}=320$ ).

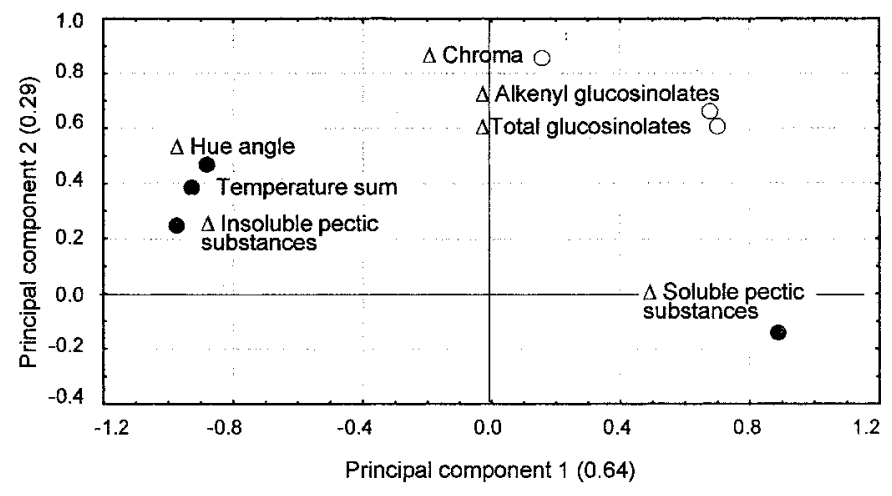

Fig. 4. Principal component analysis of $\Delta$ color values, $\Delta$ compounds and temperature sum in 'Nevadar' radish during postharvest handling hold at 5 to $8^{\circ} \mathrm{C}$ and $18{ }^{\circ} \mathrm{C}$ up to $4 \mathrm{~d}$ of storage (BBCH 43 to $49 ; \mathrm{n}=320$ ). Open symbols (O) represent the correlation between chroma and the glucosinolates, closed symbols $(\bullet)$ represent the correlation between hue angle, temperature sum and pectic substances.
Temperature also affected the pectic fractions (Fig. 3). An increase in temperature sum led to losses of insoluble pectic substances and an increase in soluble pectin. This temperature effect was supported by a principal component analysis, which was carried out to describe the relationship between the color ( $\Delta$ hue angle, $\Delta$ chroma), internal quality characteristics, and the temperature sum during postharvest handling (Fig. 4). The first principal component (PC1) containing 64\%, and the second principal component (PC2) containing $29 \%$ were plotted in two dimensional space. The $\Delta$ insoluble pectic substances and the temperature sum during postharvest handling rated high on $\mathrm{PC} 1$ $(-0.97$ and -0.90 , respectively). Increasing temperatures may have stimulated pectolytic enzyme activity and thus, the degradation of insoluble pectic substances. A second reaction may have been the increase in soluble pectic substances, which also showed a high, positive rate to PC1 (0.96). The accumulation and degradation of pectic substances was considered to be associated with $\Delta$ hue angle, which also contributed to PC1 with a high negative loading $(-0.85)$ : equally directed with $\Delta$ insoluble pectic substances, adversely associated with $\Delta$ soluble pectic substances. Moreover, $\Delta$ hue angle and the temperature sum rated high on PC1 ( -0.85 and -0.90 , respectively), indicating that $\Delta$ hue angle is temperature sensitive (Fig. 4).

Fluctuations in $\Delta$ insoluble pectic substances, $\Delta$ soluble pectic substances, and $\Delta$ hue angle could be caused by the temperature dependency of both pectin (Tijskens and Rodis, 1997; Tijskens and van Dijk, 2000) and color-determining anthocyanins (Böhm et al., 1998; Gennaro et al., 2002; Herrmann, 1991; Marais et al., 2001; Romero and Bakker, 2000; Wang and Stretch, 2001) resulting in a strong correlation between $\Delta$ hue angle and $\Delta$ pectic fractions ( $r^{2}=0.94$ and $r^{2}=0.96$, respectively) (Fig. 1).

CORRELATION BETWEEN ROOT COLOR AND GLUCOSINOLATES. Changes in glucosinolates also responded to color changes after harvest. Yet, $\Delta$ glucosinolates were characterized by changes in $\Delta$ chroma, but not by $\Delta$ hue angle (Fig. 5). Principal component analysis also demonstrated that $\Delta$ chroma, $\Delta$ alkenyl, and $\Delta$ total glucosinolates rated relatively high in PC2 $(0.87,0.65$, and 0.63 , respectively) and hence showed a close relationship to each component (Fig. 4).

The indolyl glucosinolates, glucobrassicin and 4-methoxyglucobrassicin, were identified in 'Nevadar' radish roots (Widell et al., 1998). Postharvest conditions did not appear to affect $\Delta$ indolyl glucosinolates, whereas they affected $\Delta$ alkenyl glucosinolates (progoitrin, glucoraphenin and glucoraphasatin) estimated

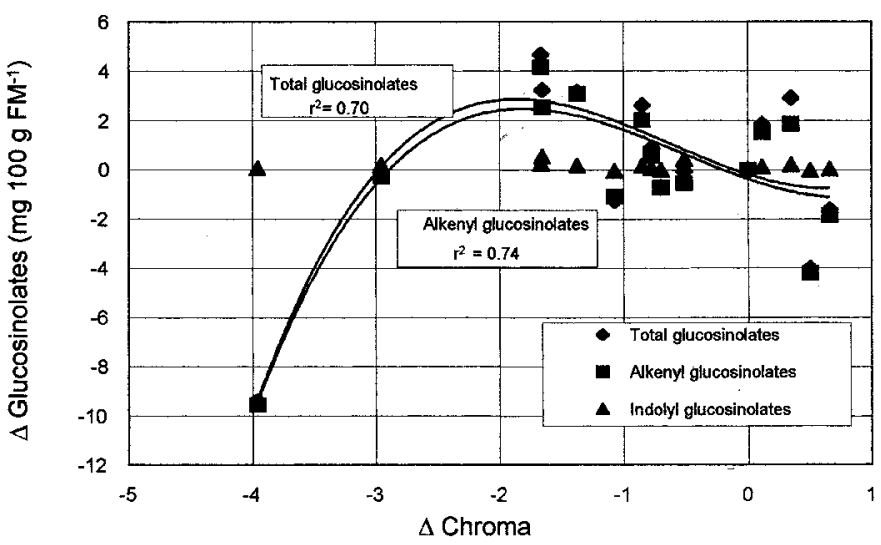

Fig. 5. Correlation between $\Delta$ glucosinolate content and $\Delta$ chroma of 'Nevadar' radish during postharvest handling hold at 5 to $8{ }^{\circ} \mathrm{C}$ and $18{ }^{\circ} \mathrm{C}$ up to $4 \mathrm{~d}$ of storage (BBCH 43 to $49 ; \mathrm{n}=320)$. 
Table 1. Maximum chlorophyll fluorescence, content of alkenyl glucosinolates and chroma of 'Nevadar' radish depending on physiological age at harvest and after $4 \mathrm{~d}$ stored at 5 to $8^{\circ} \mathrm{C}(\mathrm{n}=160)$.

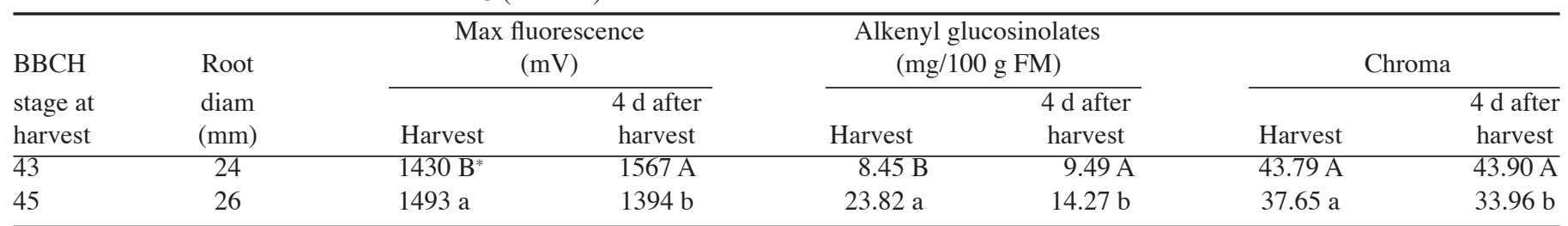

${ }^{*}$ Means within the same line containing the same letter (capital letter for BBCH stage 43 and small letter for BBCH stage 45) are not significantly different according to Tukey's HSD test $(P \leq 0.05)$.

by means of $\Delta$ chroma $\left(r^{2}=0.74\right)$ (Fig. 5). The strong decrease in glucosinolates and the decline of $\Delta$ chroma from -4 to -3 on days 3 and 4 (at 5 to $8^{\circ} \mathrm{C}$ ), respectively, is assumed to be caused by the high growth rate, which was $0.5 \mathrm{~g} \cdot \mathrm{d}^{-1}$. In contrast, radishes with a lower growth rate of 0.25 to $0.45 \mathrm{~g} \cdot \mathrm{d}^{-1}$ had lower $\Delta$ chroma values varying from -1.7 to 0.7 . Higher growth rates have been related to higher respiration rates (Böttcher 1996; Friedrich and Fischer, 2000). Therefore, it is assumed that high growth rates may have accelerated the degradation of glucosinolates and color determining anthocyanins during the postharvest treatment. Enhanced respiration rates might have caused an acceleration of internal product temperature (Kays, 1991) resulting in an enhanced degradation of the temperature sensitive anthocyanins and glucosinolates, as reported by Hermann (1991), Shattuck et al. (1991a, 1991b) and Böhm et al. (1998).

The accumulation and degradation processes of alkenyl glucosinolates were, in contrast to those of the pectins, independent of the postharvest temperature. It is assumed that they were mainly determined by the physiological age of the root. The same applies to chroma. In cabbage, Chong and Berard (1983) found that the content of glucosinolates increased during cold storage until the beginning of senescence. Thereafter, the glucosinolate content decreased rapidly. A similar effect was found during radish storage. According to Schouten et al. (1997) chlorophyll fluorescence assessment characterizes the physiological status of a harvested product corresponding to the physiological age. This is associated with changes in the expression of chlorophyll fluorescence (Schouten et al., 1997; Wills et al., 1998). Older radishes (BBCH 45) revealed a decreasing maximum fluorescence, indicating senescence, while younger radishes $(\mathrm{BBCH} 43)$ revealed an increasing or constant maximum fluorescence, and hence showed no senescence symptoms. In young radishes (BBCH 43), the lack of senescence symptoms was accompanied with an increase in alkenyl glucosinolates and with a constant chroma during postharvest treatment. In older radishes $(\mathrm{BBCH} 45)$, the senescence process corresponded with a decrease of alkenyl glucosinolates and of the chroma intensity at the end of the postharvest treatment (Table 1). The dependency of both the alkenyl glucosinolates and the chroma on developmental stage is assumingly responsible for their close correlation (Fig. 5).

CORRELATION BETWEEN ROOT COLOR AND MONOSACCHARIDES. Postharvest changes in monosaccharides (glucose, fructose) could not be described by changes in color due to the low correlation coefficient $\left(r^{2}=0.60\right)$ (data not shown). This is assumed to be caused by metabolic processes being influenced by different, or complementary, factors leading to different changes in monosaccharides and color. The high inexplicable statistic residue (0.40) calculated in this correlation might be due to the genotypic variability.

In 'Nevadar' radish, color changes ( $\Delta$ hue angle, $\Delta$ chroma) corresponded with postharvest changes of soluble and insoluble pectic substances, total glucosinolates, and alkenyl glucosinolates. These compounds are related to the sensory quality of radishes. The changes in chemical compounds were attributed to changes in postharvest temperature. A decreased redness (hue angle increased, negative $\Delta$ hue angle) corresponded with increasing contents of soluble pectin and decreasing contents of insoluble pectin, indicating senescence and an undesired loss in crispness. A decrease in chroma (negative $\Delta$ chroma) revealed a loss in total glucosinolates and alkenyl glucosinolates and, hence, an undesired loss in flavor.

Maintenance of product quality is one of the major issues in postharvest quality management strategies. In this context, quality control for early and continuous detection of quality loss by nondestructive determination is an integral part of quality assurance systems. The present investigations revealed that root color might be applied as an indicator for red radish quality and, therefore, could be used as a nondestructive, reliable and rapid tool for quality control during distribution and marketing.

\section{Literature Cited}

AISN Software Inc. 1997. TableCurve 3D. version 3.0. User's manual. AISN Software Inc., Chicago, Ill.

Berger-Schunn, A. 1994. Practical color measurement: a primer for the beginner, a reminder for the expert. Wiley, New York.

Beverly, R.B., J.G. Latimer, and D.A. Smittle. 1993. Preharvest physiological and cultural effects on postharvest quality, p. 74-98. In: R.L. Shewfelt and S.E. Prussia (eds.). Postharvest handling: A system approach. Academic Press, San Diego, Calif.

Bickelmann, U. 1996. Leitfaden für die Anwendung der EG-Qualitätsnormen für frisches Obst, Gemüse und Citrusfrüchte. Rheinischer Landwirtschaftsverlag, Bonn, Germany. p. 108.

Bleiholder, H., L. Buhr, C. Feller, H. Hack, M. Hess, R. Klose, U. Meier, R. Stauss, T. van den Boom, and E. Weber. 1997. Growth stages of mono- and dicotyledonous plants. BBCH-Monogr. Blackwell, Berlin, Germany.

Blumenkrantz, N. and G. Asboe-Hansen. 1973. New method for quantitative determination of uronic acids. Anal. Biochem. 54:484-489.

Böhm, H., H. Boeing, J. Hempel, B. Raab, and A. Kroke. 1998. Flavonole, Flavone und Anthocyane als natürliche Antioxidantien der Nahrung und ihre mögliche Rolle bei der Prävention chronischer Erkrankung. Z. Ernährungswiss. 37:147-163.

Boehringer Mannheim. 1986. Methoden der enzymatischen Lebensmittelanalytik. Boehringer Mannheim GmbH.

Böttcher, H. 1996. Frischhaltung und Lagerung von Gemüse. Verlag Eugen Ulmer, Stuttgart, Germany.

Chong, C. and L. Berard. 1983. Changes in glucosinolates during refrigerated storage of cabbage. J. Amer. Soc. Hort. Sci. 108:688-691.

De Bardemaeker, J. 1993. Quality sensing for the European market of fruits and vegetables. Proc. Amer. Soc. Agr. Eng. 1:9-22.

Friedrich, G. and M. Fischer. 2000. Physiologische Grundlagen des Obstbaues. Verlag Eugen Ulmer, Stuttgart, Germany. 
Forkmann, G. 1994. Genetics of flavonoids, p. 537-564. In: J.B. Harborne (ed.). The flavonoids. Chapman \& Hall, London.

Gennaro, L., C. Leonardi, F. Esposito, M. Salucci, G. Maiani, G. Quaglia, and V. Fogliano. 2002. Flavonoid and carbohydrate contents in Tropea red onions: Effects of homelike peeling and storage. J. Agr. Food Chem. 50:1904-1910.

Giovanelli, G. and V. Lavelli. 2002. Evaluation of heat and oxidative damage during storage of processed tomato products. I. Study of heat damage indices. J. Sci. Food. Agr. 82:1263-1267.

Gnanasekharan, V., R.L. Shewfelt, and M. Chinnan. 1992. Detection of color changes in green vegetables. J. Food Sci. 57:149-154.

Hardin, C. 1990. Why color? Perceiving, measuring, and using color. Soc. Photo-Optical Instrumentation Eng. 1250:293-300.

Herrmann, K. 1991. Vorkommen, Gehalte und Bedeutung von Inhaltsstoffen des Obstes und Gemüses. II. Flavonoide: Catechine, Proanthocyanide, Anthocyanide. Die industrielle Obst- und Gemüseverwertung 5-6:170-175.

Herrmann, K. 1997. Inhaltsstoffe der Radieschen und Rettiche. Die industrielle Obst- und Gemüseverwertung 8:240-246.

Holcroft, D.M. and A.A. Kader. 1999. Controlled atmosphere-induced changes in $\mathrm{pH}$ and organic acid metabolism may affect color of stored strawberry fruit. Postharvest Biol. Technol. 17:19-32.

Huyskens, S. 1991. Morphological, physiological and biochemical aspects in the cultivation of two pantropical cucurbits: Luffa acutangula L., Roxb. and Momordica charantia L. PhD diss. Rheinische Friedrich-Wilhelms-Universität, Bonn, Germany.

Huyskens-Keil, S., M. Schreiner, and S. Widell. 1998. Qualitätssicherung bei Radies. Taspo-Magazin 2:40-41.

Kader, A.A. 2002. Postharvest technology of horticultural crops. 3rd ed. Univ. Calif. Div. Agr. Nat. Resour. Publ. 3311.

Kawano, S., H. Abe, and M. Iwamoto. 1993. Novel applications of nondestructive techniques for quality evaluation of fruits and vegetables. Japan. Proc. Amer. Soc. Agr. Eng. 1:1-8.

Kays, S. 1991. Postharvest physiology and handling of perishable plant products. 1st ed. Van Nostrand-Reinhold, New York.

Kays, S. 1999. Preharvest factors affecting appearance. Postharvest Biol. Technol. 15:233-247.

Lange, R., M. Petrzika, B. Raab, and F. Linow. 1991. Zur Kenntnis der Schwefelverbindungen in Raps-(Brassica napus) Varietäten und Verarbeitungsprodukten. Die Nahrung 35:385-389.

Lennernäs, M., C. Fjellström, I. Giachetti, A. Schmitt, A. de Winter, and M. Kearny.1997. Influences on food choice perceived to be important by nationally-representative samples of adults in the European Union. Eur. J. Clin. Nutr. 51:8-15.

Marais, E., G. Jacobs, and D.A. Holcroft. 2001. Colour response of 'Cripps pink' apples to postharvest irradiation is influenced by maturity and temperature. Scientia Hort. 90:31-41.

Mazza, G. and E. Miniati. 1993. Anthocyanins in fruits, vegetables, and grains. CRC Press, Boca Raton, Fla.

McComb, E. and R. McCready. 1952. Colorimetric determination of pectic substances. Anal. Biochem. 24:1630-1632.

Rasch, R., V. Guiard, and G. Nürnberg. 1992. Statistische Versuchsplanung: Einführung in die Methoden und Anwendungen des Dialogsystems CADEMO. Gustav Fischer, Stuttgart, Germany.

Romero, C. and J. Bakker. 2000. Effect of storage temperature and pyruvate on kinetics of anthocyanin degradation, vitisin A derivative formation, and color characteristics of model solutions. J. Agr. Food Chem. 48:2135-2141.

Schouten, R.E., E.C. Otma, O. van Kooten, and L.M. Tijskens. 1997. Keeping quality of cucumber fruits predicted by biological age. Postharvest Biol. Technol. 12:175-181.

Schreiner, M., S. Huyskens-Keil, P. Peters, S. Widell, I. Schonhof, and A. Krumbein. 2000. Importance of produt color for the total quality management, p. 109-118. In: W. Florkowski, S.E. Prussia, and R.L. Shewfelt (eds.). Fruit and vegetable quality: An integrated view. Technomic Publ. Inc., Lancaster, Pa.

Schreiner, M., I. Schonhof, S. Widell, A. Krumbein, P. Peters, H. Auerswald, S. Huyskens-Keil, and M. Linke. 1999. Qualität von Radies. Annu. Rpt. 1998 Inst. Veg. Ornamental Crops. Großbeeren/Erfurt e.V., Großbeeren. p. 83.

Shattuck, V.I., Y. Kakuda, B.J. Shelp, and N. Kakuda. 1991a. Chemical composition of turnip roots stored or intermittently grown at low temperature. J. Amer. Soc. Hort. Sci. 116:818-822.

Shattuck, V.I., Y. Kakuda, and B.J. Shelp. 1991b. Effect of low temperature on the sugar and glucosinolate content of rutabaga. Scientia Hort. 48:9-19.

Shewfelt, R.L. and S.E. Prussia. 1993. Challenges in handling fresh fruits and vegetables, p. 27-41. In: R.L. Shewfelt and S.E. Prussia (eds.). Postharvest handling: A system approach. Academic Press Inc., San Diego, Calif.

StatSoft Inc. 2001. Electronic Textbook StatSoft. StatSoft Inc., Tulsa, Okla.

Tijskens, L.M.M. and C. van Dijk. 2000. Enzyme activity and firmness in tomatoes, p. 73-79. In: W. Florkowski, S.E. Prussia, and R.L. Shewfelt (eds.). Fruit and vegetable quality: An integrated view. Technomic Publi. Inc., Lancaster, Pa.

Tijskens,L.M.M. andP.S. Rodis. 1997. Kinetics of enzymeactivity in peaches during storage and processing. Food Technol. Biotechnol. 35:45-50.

Tollner, E.W., J.K. Brecht, and B.L. Upchurch. 1993. Nondestructive evaluation: detection of external and internal attributes frequently associated with quality or damage, p. 227-255. In: R.L. Shewfelt and S.E. Prussia (eds.). Postharvest handling: A system approach. Academic Press Inc., San Diego, Calif.

van Kooten, O. and J. Snel. 1990. The use of chlorophyll fluorescence nomenclature in plant stress physiology. Photosyn. Res. 25:147-150.

Voss, D. 1992. Relating colorimeter measurement of plant color to the royal horticultural society color chart. HortScience 27:1256-1260.

Wang, S.Y. and A.W. Stretch. 2001. Antioxidant capacity in cranberry is influenced by cultivar and storage temperature. J. Agr. Food Chem. 49:969-974.

Widell, S., A. Krumbein, and H. Auerswald. 1998. Glucosinolate in Radies und sensorische Bewertung. Proc. XXXV Annu. Mtg. German Hort. Soc. 35:151.

Wills, R., T. Lee, D. Graham, W. McGlasson, and E. Hall. 1998. Postharvest, an introduction to the physiology and handling of fruit and vegetables. UNSW Press, Sydney, Australia.

Winkhoff, J. 1992. Integrierter Anbau von Gemüse in der Bundesrepublik Deutschland. Zentralverband Gartenbau, Bundesfachgruppe Gemüsebau, Bonn, Germany.

Winter, F., H. Janssen, W. Kennel, H. Link, F. Scherr, R. Silbereisen, and J. Streif. 1992. Lucas' Anleitung zum Obstbau. Eugen Ulmer, Stuttgart, Germany. 